\title{
Maternity Benefit Practices at NGOs in Bangladesh: Laws and Implementation
}

\author{
Omar Faroque ${ }^{1}$, Md. Rafiqul Islam ${ }^{2 *}$, Md. Obaidur Rahman ${ }^{2}$, Md. Mominul Islam ${ }^{3}$ \\ ${ }^{1}$ Department of Business Administration, Northern University Bangladesh, Dhaka, Bangladsh \\ ${ }^{2}$ Department of Population Science and HRD, University of Rajshahi, Rajshahi, Bangladesh \\ ${ }^{3}$ Department of Law, Northern University Bangladesh, Dhaka, Bangladesh \\ Email: omar_ntcu@yahoo.com, rrafique_pops@yahoo.com, obaidur006@yahoo.com, \\ mominul_law@yahoo.com
}

Received October $1^{\text {st }}, 2013$; revised November $2^{\text {nd }}, 2013$; accepted November $28^{\text {th }}, 2013$

Copyright (C) 2013 Omar Faroque et al. This is an open access article distributed under the Creative Commons Attribution License, which permits unrestricted use, distribution, and reproduction in any medium, provided the original work is properly cited.

\begin{abstract}
Maternity leave is an important benefit to the female employees and it plays important role to increase organizational loyalty, efficiency and job satisfaction, particularly in the Non-Government Organizations (NGOs). The objective of the study is to assess the laws and implementation of the maternity benefits at the diverse NGOs on different working echelon in Bangladesh. Descriptive statistics and zero order correlation method have been performed using the data haul out from one hundred female employees experiencing at least one child at the different NGOs in Kurigram District, Bangladesh. Among all female employees, salary structure and the managerial position are not satisfactory at NGOs in Bangladesh, although higher education of females plays an important role to get the job. In case of maternity benefits, all of them have got three or four months as maternity leave period and a significant number have not got any types of payment during maternity leave $(27 \%)$, have not enjoyed maternity leave properly $(24 \%)$, and have been terminated, sent away or expelled etc. due to maternity leave (19\%). In addition, an inverse relation of duration of maternity leave with age $(26.4 \%)$ and length of service $(34.1 \%)$ has also been identified i.e., duration of maternity leave decreases with increasing employees' age and length of services. In our study, evidently there are no NGO practices laws of maternity benefit properly in Bangladesh. Therefore, every NGO should administer and implement the Laws of maternity benefit properly.
\end{abstract}

Keywords: Maternity Benefit; Descriptive Statistics; Zero Order Correlation; Non-Government Organizations (NGOs); Bangladesh

\section{Introduction}

NGO (Non-Government Organization) is very well known and their activities are wide spread in Bangladesh (Begum et al., 2004). NGO refers to "association voluntary formed by individuals for the purpose of rendering welfare and development services outside Government Structure: drawing funds from national and international sources; and functioning within the legal framework of the country" (Halim, 1993), "non-profitable organization" (Rahman, 2000). In Bangladesh, there were 1925 NGOs in 2004 (NFB, 2004) and the number is 2198 in 2012 (BFF, 2012). In recent years, many countries have observed a large increase in female labor force participation rates and mothers with young children increasing the most (Dustmann \& Schonberg, 2008, 2011); the labor force participation of women worldwide is $43 \%$ and the number of women workers has also gone up in the last 20 years in Bangladesh. NGOs have contributed greatly to the employment generation in Bangladesh (World Bank Group's Database), mostly in women employment and in 2010, the 126 (Micro Finance Institution) MFINGOs created direct 37,773 women employments (BMFS, 2010). Thus, maternity leave is an issue, since the majority

\footnotetext{
*Corresponding author.
}

women have child at their lives (Anam, 2008).

"Maternity Benefit" means leave with wages granted to a female worker because of her giving birth to a child (Paul, 2008). Maternity is a condition which requires differential treatment to achieve genuine equality and, in this sense, it is more of a premise of the principle of equality than a dispensation (ILO, 1996). Generally, maternity leave is available to mothers only (Thevenon \& Solaz, 2013). At first, maternity leaves were introduced to protect the health of working mothers and their newborn child (Thevenon \& Solaz, 2013), to protect female workers from heavy work conditions, and later, to preserve job opportunities of young mothers who want to return job after birth (Zhelyazkova, 2013). Parental leave or maternity leave is an important employee benefit (Dessler, 2008). Maternity leave is important as future cognitive and emotional development (Harris, 1983; Lewis \& Brooks-Gunn, 1979); to improve the welfare of children, and expansions, increase in the quantity and quality of child-parent interactions (Dustmann \& Schonberg, 2008, 2011). It is also important for the health and wellbeing of mothers and children; child development; family formation and functionality; women's labor-force attachment and career progression; and gender equality in paid employment and the household (Galtry \& Callister, 2005; Carneiro et 
al., 2011; Whitehouse et al., 2008) and reducing maternal and child mortality (Younes et al., 2012). Mostly it is important to facilitate breastfeeding and to prevent some adverse health consequences for the mother and child (Barger et al., 2005); raise the labor market participation (Bainchi, 2000; Gauther et al., 2004; Sayer et al., 2004; Kan et al., 2011) and avoid many unobservable attributes that affect child development (Dustmann \& Schonberg, 2008, 2011; Carneiro et al., 2011). Maternity benefits promote children's development (Hays, 1996; Bainchi et al., 2006), increase level of gender inequality (Hook, 2010; Lalive et al., 2011) and leave regulations guarantee the pre-birth job and offer financial support (Lalive et al., 2011). There is significant evidence that child developmental outcomes are generally better if mothers do not work, or do not work full time, in the first year of life; and vice-versa (BrooksGunn et al., 2002; Ruhm, 2004).

In Bangladesh, workers got Maternity Leave for 12 weeks (Maternity Benefit Act, 1939), then 16 weeks (Ministry of Labour and Employment, 2006) and now 24 weeks (Department of Finance, 2012) with full pay whereas some Asian countries like Iran 6 months, India 84 days (180 days for employees of Central Government), Viet Nam 4 months; Singapore 16 weeks, Indonesia, Korea, China and Cambodia 90 days; Sri Lanka 12 weeks, Saudi Arab 10 weeks; Yemen, Malaysia and Philippine 60 days; and UAE 45 days (ILO, 2010; Department of Personnel and Training, 2008; Sadek, 2012; BNG Legal, 2010); some developed countries like Germany 42 weeks, Sweden 40 weeks, Norway 38 weeks, Greece 34 weeks, Canada 29 weeks, Finland 29 weeks and Japan 26 weeks. In USA, the Family and medical leave Act of 1993 (FMLA) mandates up to 12 weeks of (potentially unpaid) job protected leave, including parental leave, for many American workers. Other developed countries provide leave between 11 to 26 weeks as Austria, Belgium, Denmark, France, Ireland, Italy, Netherland, New Zealand, Portugal, Spain, Switzerland and United Kingdom (Long, 2012; Ray et al., 2009). In the South America, maternity leave is paid as Brazil, 120 days in private and 180 days in public sector; Chile, Cuba and Venezuela 18 weeks; Costar Rica 16 weeks, Argentina, Bolivia and Peru 90 days; Panama and Belize 14 weeks; Antigua, Barbuda and Uruguay 13 weeks; and Colombia, Haiti, Mexico and Paraguay 12 weeks each. In the African countries, maternity leave is paid as South Africa 4 months, Congo 15 weeks; Egypt and Libya 90 days; Algeria, Cameroon, Chad, Morocco, Mali, Senegal and Togo 14 weeks; and Ghana, Nigeria and Zambia 12 weeks each (ILO, 2010; Pautassi \& Rico, 2011). At present, Australia introduced an 18 -week paid maternity leave scheme starting from 2011 and UK paid 52 weeks which is the longest in the world (Thevenon \& Solaz, 2013; AusGov, 2010; NHS Staff Council, 2013).

There are huge inequalities in maternity leave privileges across different countries. On one hand, countries in Northern Europe; such as Sweden, Norway or Germany; mandate very generous paid leave and long periods of job protection after birth. On the other hand, there are few countries, such as United States, which have no paid leave mandate and offer little job protection (Carneiro et al., 2011; Schober, 2012). In the global, Austria, Bulgaria, Denmark, France, Netherlands, Spain, Switzerland etc. in Europe; Argentina, Brazil, Chile, Cuba, Mexico, Peru, Venezuela etc. in South and North America; Algeria, Cameroon, Congo, Egypt, Morocco etc. in Africa; and India, Indonesia, Iran, Korea, Malaysia, Singapore, Saudi Arab, Sri Lanka, Jordan etc. in Asia provide 100\% benefit; like these countries, Bangladesh also provides $100 \%$ benefit to the female workers. In some countries, cash benefits are only available for a certain number of births. In Malaysia, cash benefits are provided for a women's first five children; in Egypt, three times during a spell of employment; whereas in Bangladesh, only for two children in the whole employment (ILO, 2010).

In Bangladesh, there was some discrimination found in maternity leave administration in few sectors. It was seen in the garment sector that most women were restricted to leave their jobs after the birth of their children and if they hunted to start work again in the same factory they would have to start as new employees with lower wages and salaries instead of returning to their former positions; and some owners provided leave to their employees but did not pay them as per the provisions of the Law (Anam, 2008). This study shows a scenario of the maternity benefits practices at the different NGOs on the world context as well as local in Bangladesh. Such kinds of studies are very poor in Bangladesh. This study helps to fill up the existing research gap. The objective of this study is to evaluate the laws and implementation of the maternity leave at the different NGOs on different working position in Bangladesh and also identify the level of termination, discharge, dismission and discrimination during employees leave period.

\section{Laws of Maternity Leave}

\section{International Laws: Duration of Leave}

"... a woman to whom this Convention applies shall be entitled to a period of maternity leave of not less than 14 weeks" [Convention No. 183, Article 4(1)].

"Members should Endeavour to extend the period of maternity leave referred to in Article 4 of the Convention to at least 18 weeks" [Recommendation No. 191, Paragraph 1(1)].

"With due regard to the protection of the health of the mother and that of the child, maternity leave shall include a period of six weeks' compulsory leave after childbirth, unless otherwise agreed at the national level by the government and the representative organizations of employers and workers" [Convention No. 183, Article 4(4)].

"To the extent possible, measures should be taken to ensure that the woman is entitled to choose freely the time at which she takes any non-compulsory portion of her maternity leave, before or after childbirth" [Recommendation No. 191, Paragraph $1(3)]$.

\section{Cash Benefits}

"Cash benefits shall be provided, in accordance with national laws and regulations, or in any other manner consistent with national practice, to women who are absent from work on leave" [Convention No. 183, Article 6(1)].

\section{Amount and Duration}

"Cash benefits shall be at a level which ensures that the woman can maintain herself and her child in proper conditions of health and with a suitable standard of living" [Convention No. 183, Article 6(2)].

"Where, under national law or practice, cash benefits paid with respect to leave referred to in Article 4 are based on previous earnings, the amount of such benefits shall not be less than two-thirds of the woman's previous earnings or of such of 
those earnings as are taken into account for the purpose of computing benefits" [Convention No. 183, Article 6(3)].

"Where, under national law or practice, other methods are used to determine the cash benefits paid with respect to leave referred to in Article 4, the amount of such benefits shall be comparable to the amount resulting on average from the application of the preceding paragraph" [Convention No. 183, Article 6(4)].

"Where practicable, and after consultation with the representative organizations of employers and workers, the cash benefits to which a woman is entitled during leave referred to in Articles 4 and 5 of the Convention should be raised to the full amount of the woman's previous earnings or of such of those earnings as are taken into account for the purpose of computing benefits" [Recommendation No. 191, Paragraph 2] (ILO, 2010).

\section{Local Laws: Right to, and Liability for, Payment of Maternity Benefit}

1) Every woman employed in an establishment shall be entitled to and her employer shall be liable for, the payment of maternity benefit in respect of the period of eight weeks preceding the expected day of her delivery and eight weeks immediately following the day of her delivery:

Provided that a woman shall not be entitled to such maternity benefit unless she has worked under the employer, for a period of not less than six month immediately preceding the day of her delivery.

2) No maternity benefit shall be payable to any woman if at the time of her confinement she has two or more surviving children, but in that case she shall be entitled to the leave to which she would otherwise be entitled [Section-46].

\section{Procedure Regarding Payment of Maternity Benefit}

1) Any pregnant woman entitled to maternity benefit under this act may, on any day, give notice either orally or in writing to her employer that she expects to be confined within eight weeks next following and may therein nominate a person for purposes of receiving payment of maternity benefit in case of her death.

2) Any woman who has not given such notice and has been delivered of a child, shall within seven days, give similar notice to her employer that she has given birth to a child.

3) When a notice referred to in Sub-section 1 or 2 is received, the employer shall permit the women to absent herself from work from the day following the date of notice in the case mentioned in Sub-section 1; form the day of delivery in the case mentioned in Sub-section 2 until eight weeks after the day of delivery.

4) An employer shall pay maternity benefit to a woman entitled thereto in such one of the following ways as the woman desire, namely:

a) for eight weeks, within three working days of the production of a certificate signed by registered medical practitioner stating that the woman is expected to be confined within eight weeks of the date of the certificate, and for the remainder of the period for which she is entitled to maternity benefit under this act within three working days of the production of proof that she has given birth to a child; or

b) for the said period up to and including the day of delivery, within three working days of the production of proof that she has given birth to a child, and for the remainder of the said period, within eight weeks of the production of such proof; or

c) for the whole of the said period, within three working days of the production of proof that she has given birth to a child:

Provided that a woman shall not be entitled to any maternity benefit or any part thereof, the payment of which is dependent upon the production of proof under this sub-section that she has given birth to a child, unless, such proof is produced within three months of the day of her delivery.

5) The proof required to be produced under Sub-section 4 shall be either a certified extract from a birth register under the births and deaths registration act, 2004 (XXIX of 2004) or a certificate signed by a registered medical practitioner or such other proof as may be accepted by the employer [Sction-47].

\section{Amount of Maternity Benefit}

1) The maternity benefit which is payable under this act shall be payable at the rate of daily, weekly or monthly average wages, as the case may be, calculated in the manner laid down in Sub-section 2, and such payment shall be made wholly in cash.

2) For the purpose of Sub-section 1 the daily, weekly or monthly average wages, as the case may be, shall be calculated by dividing the total wages earned by the woman during the three months immediately preceding the date on which she gives notice under this act by the number of day she actually worked during the period [Section-48].

\section{Restriction on Termination of Employment of a Woman in Certain Cases}

If any notice or order of discharge, dismissal, removal or termination of employment is given by an employer to a woman within a period of six month before and eight weeks after her delivery and such notice or order is given without sufficient cause, she will not be deprived of any maternity benefit to which she would have become entitled under this chapter [Section-50] (Ministry of Labour and Employment, 2006).

\section{Amended Maternity Leave}

"Where a female Government servant applies for maternity leave, the authority mentioned in rule 149 or, rule 150, as the case may be, shall grant such leave for a period of six months from the date of commencement of the leave or her confinement for the purpose of delivery, whichever is earlier". This amended leave was effective from 09 January, 2011 (Department of Finance, 2012).

\section{Data and Methods}

This is a cross sectional studies involving 100 female employees of all ages who have at least one child and are experienced in maternity leave extracted from various non-government organizations (NGOs) in Kurigram District, Bangladesh. Data on some selected socio-economic and maternity leave related factors have been collected through questionnaire method during November to December, 2012. To fulfill the objective, descriptive statistics and zero order correlation method have been utilized in this study. Initially, the descriptive statistics has been used to explore the current situation of 
socio-economic and maternity leave related characteristics of the respondents and finally, zero order correlation method have been employed to estimate the existence relationships among them. The analyses of the data have been made using the statistical software SPSS-20 version.

\section{Results and Discussion}

The results of descriptive statistics have been demonstrated in Table 1 where the frequency with percentage distribution of

Table 1.

Socio-demographic and maternity leave related characteristics of employees at NGOs in Bangladesh.

\begin{tabular}{|c|c|c|}
\hline Characteristics & Frequency & Percentage \\
\hline \multicolumn{3}{|l|}{ Age Group } \\
\hline $20-24$ years & 24 & 24 \\
\hline $25-29$ years & 58 & 58 \\
\hline $30-40$ years & 18 & 18 \\
\hline \multicolumn{3}{|l|}{ Education } \\
\hline SSC pass & 24 & 24 \\
\hline HSC pass & 27 & 27 \\
\hline Higher & 49 & 49 \\
\hline \multicolumn{3}{|l|}{ Current Place of Living } \\
\hline Sub-urban & 58 & 58 \\
\hline Rural & 42 & 42 \\
\hline \multicolumn{3}{|l|}{ Monthly Salary } \\
\hline$\leq$ TK. 10000 & 46 & 46 \\
\hline TK. $10100-15000$ & 41 & 41 \\
\hline$>$ TK. 15000 & 13 & 13 \\
\hline \multicolumn{3}{|l|}{ Level of Present Job } \\
\hline Managerial personnel & 2 & 2 \\
\hline Officer & 49 & 49 \\
\hline Field worker & 49 & 49 \\
\hline \multicolumn{3}{|l|}{ Worth/Skill of Employee } \\
\hline Under training & 5 & 5 \\
\hline Trained & 40 & 40 \\
\hline Experienced & 55 & 55 \\
\hline \multicolumn{3}{|l|}{ Length of Present Service } \\
\hline $1-2$ years & 23 & 23 \\
\hline 3 years & 39 & 39 \\
\hline 4 years & 20 & 20 \\
\hline 5 years and above & 18 & 18 \\
\hline \multicolumn{3}{|l|}{ Rule of Maternity Leave at NGOs } \\
\hline For 1 st children & 1 & 1 \\
\hline For 1 st and 2 nd children & 99 & 99 \\
\hline \multicolumn{3}{|l|}{ Duration of Maternity Leave } \\
\hline 3 months & 29 & 29 \\
\hline 4 months & 71 & 71 \\
\hline \multicolumn{3}{|l|}{ Leave Permissible } \\
\hline From the date of joining & 99 & 99 \\
\hline After conformation & 1 & 1 \\
\hline \multicolumn{3}{|l|}{ Payment of Maternity Leave } \\
\hline With full pay & 67 & 67 \\
\hline With half pay & 6 & 6 \\
\hline Without pay & 27 & 27 \\
\hline \multicolumn{3}{|l|}{ Style of Maternity Leave } \\
\hline Before $50 \%$ and after $50 \%$ & 100 & 100 \\
\hline \multicolumn{3}{|c|}{ Properly Enjoyed Maternity Leave } \\
\hline Yes & 76 & 76 \\
\hline No & 24 & 24 \\
\hline \multicolumn{3}{|c|}{$\begin{array}{l}\text { Termination, dismiss or discharge } \\
\text { due to Maternity Leave }\end{array}$} \\
\hline Yes & 19 & 19 \\
\hline No & 81 & 81 \\
\hline
\end{tabular}

the selected socio-demographic and maternity leave related characteristics of employees at NGOs in Bangladesh is disclosed. It is observed from Table 1 that most of the female employees $(58 \%)$ are belonged to the 25 - 29 years of age groups. Also, $24 \%$ and $18 \%$ employees are in the $20-24$ years and $30-40$ years of age groups respectively. There are $24 \%$, $27 \%$ and $49 \%$ employees who have completed SSC, HSC and Higher level of education. It implies that higher education plays a vital role to get the job at NGOs in Bangladesh, especially for females. Among all employees, $58 \%$ and $42 \%$ are currently lived in sub-urban and rural areas respectively. Again, there are $46 \%, 41 \%$ and $13 \%$ employees who get $\leq \mathrm{TK}$. 10000 , TK. $10100-15000$ and >TK. 15000 as monthly salary respectively. Clearly, the salary structure of the employees is not good enough because the livelihood costs is rapidly increasing in Bangladesh. So, it is important to increase the salary structure of employees. It is also observed that the level of job of female employees is not satisfactory. Only $2 \%$ employees are managerial personnel. In case of officer and field worker, both contains equal personnel (49\%). Of all employees, the majorities (55\%) are experienced personnel and the rests are in under training $(5 \%)$ and trained (40\%). Again, there are 23\%, 39\%, 20\% and $18 \%$ employees whose length of present service is $1-2$ years, 3 years, 4 years and $\geq 5$ years respectively. It implies that the number of employees decreases with increasing the length of services. In case of maternity leave practices, it is observed that only $1 \%$ employees have got the maternity leave for first children but the rests (99\%) have got this leave for first and second children, which implies that NGOs of Bangladesh follow the rule of government in this case. But in case of duration of maternity leave practices, they don't follow the governments' rule. Although the governments' rule of duration of maternity leave in Bangladesh is six months, NGOs give three or four months leave which has been observed in this study. Although the majorities (71\%) have got four months as maternity leave, $29 \%$ of employees have got three months. About all (99\%) have got this leave from the date of joining but $1 \%$ has got after the conformation of job. Clearly, it is also positive sign for job satisfaction. It is also observed that the majorities (73\%) have got any type of payment of maternity leave where $67 \%$ get full payment and $6 \%$ get half payment of leave, but a remarkable number of employees (27\%) have not got any types of payment during leave. Since cash benefits of maternity is legal rights of employees, every NGO should have to give the full payment system. However, every NGO in Bangladesh gives the before $50 \%$ and after $50 \%$ maternity leave which is observed in this study. Although, most of the employees (76\%) have enjoyed maternity leave properly, a remarkable number (24\%) have not enjoyed properly. In addition, $19 \%$ employees have been terminated from NGOs in Bangladesh due to maternity leave. So, it is important to ensure the job of employees and NGOs must follow the governments' rule of maternity leave.

The Table 2 depicts the results of zero order correlation coefficients of socio-economic and maternity leave related characteristics of employees at NGOs in Bangladesh. It is found from the results that employees' age is significantly correlated with education, monthly salary, length of present service and duration of maternity leave. Moreover, a significant correlation has been found between education and monthly salary, monthly salary and length of service, length of service and duration of maternity leave respectively.

There are $61 \%, 71.2 \%$ and $58 \%$ positive correlations of em- 
Table 2.

Zero order correlation coefficients of socio-economic and maternity leave related characteristics.

\begin{tabular}{cccccc}
\hline & Age & Education & $\begin{array}{c}\text { Monthly } \\
\text { Salary }\end{array}$ & $\begin{array}{c}\text { Length } \\
\text { of } \\
\text { Present } \\
\text { Service }\end{array}$ & $\begin{array}{c}\text { Duration } \\
\text { of } \\
\text { Maternity } \\
\text { Leave }\end{array}$ \\
\hline Age & 1 & 0.610 & 0.712 & 0.580 & -0.264 \\
Education & $(0.000)$ & $(0.000)$ & $(0.000)$ & $(0.004)$ \\
Monthly & 1 & 0.839 & 0.020 & 0.108 \\
Salary & & $(0.000)$ & $(0.421)$ & $(0.142)$ \\
$\begin{array}{c}\text { Length of } \\
\text { Present } \\
\text { Service }\end{array}$ & & 1 & 0.263 & 0.018 \\
$\begin{array}{c}\text { Duration } \\
\text { of }\end{array}$ & & & & & \\
Maternity \\
Leave
\end{tabular}

Note: The value of () indicates the $\rho$ value.

ployees' age with education, monthly salary and length of service, but $26.4 \%$ negative correlation with duration of maternity leave respectively. Clearly, education, monthly salary and length of service increases with increasing the age of employees but in case of duration of maternity leave, it has a reverse relationship. A positive correlation between education and monthly salary $(83.9 \%)$ and monthly salary and length of service $(26.3 \%)$ but a negative correlation between length of service and duration of maternity leave $(34.1 \%)$ has also been found. It clarifies that monthly salary increases with increasing education and length of service respectively. Despite increasing length of services, duration of maternity leave decreases. However, the relationships of these factors have been shown in Figure 1 for making clear understanding.

\section{Conclusion and Recommendation}

In this study, about half of the female employees belong to the 25 - 29 years of age groups (58\%) and have higher level of education (49\%). Although higher education plays a vital role to get the job particularly for females at NGOs in Bangladesh, the salary structure of the employees is not satisfactory because the living cost is rapidly increasing in this country. In addition, the level of job of female employees is not satisfactory. There are only $2 \%$ managerial personnel. However, the majorities are trained $(40 \%)$ or experienced $(55 \%)$ personnel. It is also remarkable that the number of female employees decreases with increasing the length of services. In case of maternity leave practices at NGOs in Bangladesh, almost all employees (99\%) have got this leave for first and second children and they have got three or four months as maternity leave period. Clearly, the governments' rule about duration of maternity leave is six months in Bangladesh but no NGO follows this rule properly. Moreover, a remarkable number of employees have not got any types of payment during maternity leave $(27 \%)$, have not enjoyed maternity leave accurately $(24 \%)$, and have been terminated, discharged or dismissed etc. at their send-off period $(19 \%)$. There has also found a strong positive correlation of employees' age with education $(61 \%)$, monthly salary $(72.1 \%)$ and length of service (58\%); education with monthly salary

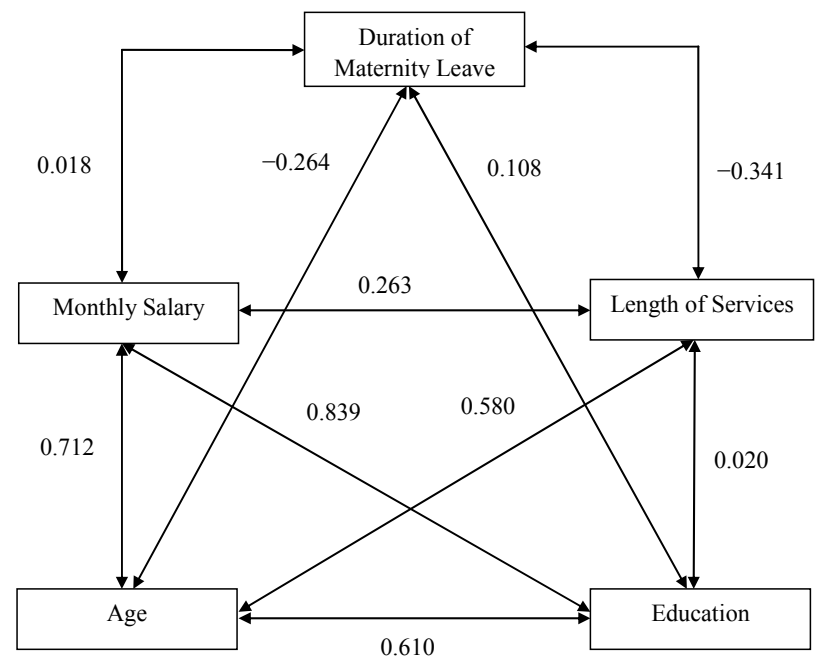

Figure 1.

Diagram of Zero Order Correlation Coefficients among the selected variables.

(83.9\%); and monthly salary with length of service $(26.3 \%)$ respectively. But, a negative correlation of duration of maternity leave with age (26.4\%) and length of service (34.1\%) has also been found, which clarifies that duration of maternity leave decreases with increasing employees' age and length of services. Therefore, it is recommended that every NGO should practice the statute of maternity benefits accurately. The findings of this study would be very helpful to the NGOs and Government; and other businesses to implement proper maternity benefits policies at their organizations to ensure the satisfaction of the employees.

\section{REFERENCES}

Anam, R. L. (2008). Inequalities and variations of maternity leave policies throughout the world: Special focus on Bangladesh. BRAC University Journal, 1, 93-98.

Australian Government (2010). Budget 2009-2010: Expense Measures'. Australian Government. http://www.budget.gov.au

Bangladesh Freedom Foundation (2012). List of NGOs, Level-5, 6/5A, Sir Sayed Road. Mohammadpur, Dhaka, 1-158.

Bangladesh Micro Finance Statistics (2010). Trends and growth of microfinance programs of MFI-NGOs in Bangladesh using panel data. Credit and Development Forum (CDF) \& Institute of Microfinance (InM), 1-30.

Begum, S. A., Zaman, S. H., \& Khan, M. S. (2004). Role of NGOs in rural poverty eradication: A Bangladesh observation. BRAC University Journal, 1, 13-22.

Berger, L. M., Hill, J., \& Waldfogel, J. (2005). Maternity leave, early maternal employment and child health and development in the US. The Economic Journal, 115, 29-47. http://dx.doi.org/10.1111/j.0013-0133.2005.00971.x

Bianchi, S. M. (2000). Maternal employment and time with children, dramatic change or surprising continuity? Demography, 37, 401-414. http://dx.doi.org/10.1353/dem.2000.0001

Bianchi, S. M., Robinson, J. P., \& Milkie, M. A. (2006). Changing Rhythms of American Family Life. Russell Sage Foundation, New York.

BNG Legal (2010). Labor Law Compliance Review for NGOs. Cambodia, 1-4.

Brooks-Gunn, J., Han, W. J., \& Waldfogel, J. (2002). Maternal employment and child cognitive outcomes in the first three years of life. Child Development, 73, 1052-1072.

http://dx.doi.org/10.1111/1467-8624.00457 
Carneiro, P., Loken, K. V., \& Salvanes, K. G. (2011). A flying start? Maternity leave benefits and long run outcomes of children. IZA Discussion Paper, IZA DP No. 5793, 1-76.

Department of Finance (2012). E-book of Finance Department of the Government of Republic Bangladesh, chapter 10, 1871-1872.

Department of Personnel and Training (2008). Recommendations of the sixth Central Pay Commission relating to enhancement of the quantum of maternity leave and introduction of child care leave in respect of Central Government Employees. Department of Personnel and Training. Ministry of Personnel, Public Grievances \& Pensions, Government of India.

Dessler, G. (2008). Human resource management. Pearson Prentice Hall, 475-485.

Dustmann, C., \& Schonberg, U. (2008). The effect of expansions in Maternity Leave Coverage on children's long-term outcomes. IZA Discussion Paper, IZA DP No. 3605, 1-50.

Dustmann, C., \& Schonberg, U. (2011). The effect of expansions in Maternity Leave Coverage and Children's long-term outcomes. American Economic Journal of Applied Economics, 4, 190-192. http://dx.doi.org/10.1257/app.4.3.190

Galtry, J., \& Callister, P. (2005). Assessing the optimal length of parental leave for child and parental wellbeing: How can research infrm policy? Journal of Family Issues, 26, 219-46. http://dx.doi.org/10.1177/0192513X04270344

Gauthier, A. H., Smeeding, T. M., \& Furstenberg, J. F. F. (2004). Are Parents Investing Less Time in Children? Trends in Selected Industrialized Countries. Population and Development Review, 30, 647671. http://dx.doi.org/10.1111/j.1728-4457.2004.00036.x

Halim, M. A. (1993). Social Welfare Legislation in Bangladesh. Dhaka, 139-140.

Harris, P. L. (1983). Infant cognition. In Handbook of Child Psychology, Socialization, Personality, and Social Development (pp. 689-782). New York: Wiley \& Sons.

Hays, S. (1996) The cultural contradictions of motherhood. Yale University Press.

Hook, J. L. (2010). Gender Inequality in the Welfare State. Task Segregation in Housework, 1965-2003. American Journal of Sociology, 115, 1480-1523. http://dx.doi.org/10.1086/651384

Hook, J. L. (2006). Care in context. Men's unpaid work in 20 countries, 1965-2003. American Sociological Review, 71, 639-660. http://dx.doi.org/10.1177/000312240607100406

ILO (1996). Equality in employment and occupation, Report III (Part 4B). International Labor Conference, Geneva.

ILO (2010). Maternity at work. A review of national legislation: Findings from the ILO Database of conditions of work and employment laws. Geneva, 1-105.

Kan, M. Y., Oriel, S., \& Jonathan, G. (2011). Gender Convergence in Domestic Work: Discerning the Effects of Interactional and Institutional Barriers in Large-Scale Data. Sociology, 45, 234-251. http://dx.doi.org/10.1177/0038038510394014

Lalive, R., Schlosser, A., Steinhauer, A., \& Zweimuller, J. (2011). Parental leave and mothers' careers: The relative importance of job protection and cash benefits. Working Paper Series 42. Department of Economics, University of Zurich, AUS.

Lewis, M., \& Brooks-Gunn, J. (1979). Social Cognition and the Acquisition of Self. New York: Plenum.

http://dx.doi.org/10.1007/978-1-4684-3566-5

Long, V. (2012). Statutory parental leave and pay in the UK: Stereotypes and Discrimination. The Equal Rights Review, 9, 52-65.

Ministry of Labour and Employment (2006). Bangladesh Labour Act 2006. Ministry of Labour and Employment, Government of Republic Bangladesh, 1-144.

(2004). NGO Affairs Bureau.

Paul, N. C. (2008). Bangladesh Labor Code 2006 \& Other Related Laws (pp. 1-99). Dhaka: Shams Publications.

Pautassi, L. C., \& Rico, M. N. (2011). Childcare Leave: A right of children and parents. Challenges, Newsletter, 12, 4-9.

Rahman, M. A. (2000). Social problems and Development. Policy, Planning and Actions (pp. 618-620). Dhaka: Koran Mahal.

Ray, R., Gornick, J. C., \& Schmitt, J. (2009). Parental leave policies in 21 countries: Assessing generosity and gender quality. Washington D. C.: Center for Economic and Policy Research.

Ruhm, C. (2004). Parental employment and child cognitive development. Journal of Human Resources, 39, 155-192. http://dx.doi.org/10.2307/3559009

Sadek, I. (2012). Maternity and Paternity rights in the UAE private sector. Habib AL Mulla \& Company.

Sayer, L. C., Bianchi, S. M., \& Robinson J. P. (2004). Are Parents Investing Less in Children? Trends in Mothers' and Fathers' Time with Children. American Journal of Sociology, 110, 1-43. http://dx.doi.org/10.1086/386270

Schober, P. S. (2012). Parental leave policies and child care time in couples after childbirth. SOEP Papers on Multidisciplinary Panel Data Research. DIW Berlin, 434, 1-43.

The NHS Staff Council (2013). NHS terms and conditions of service handbook, amendment no-28. Pay Circulars (AforC) 1 and 2/2013, UK, 73-78.

Thevenon, O., \& Solaz, A. (2013). Labour market effects of parental leave policies in OECD countries. OECD Social, Employment and Migration working papers, OECD publishing, 141, 1-68.

Whitehouse, G., Hosking, A., \& Baird, M. (2008). Returning too soon? Australian mother's satisfaction with maternity leave duration. Asia Pacific Journal of Human Resources, 46, 288-302. http://dx.doi.org/10.1177/1038411108095760.

World Bank Group's Database of Gender Statistics. http://www.worldbank.org/data-catalog/gender-statistics

Younes, L., Houweling, T. A., Azad, K., Costello, A., \& Fottrell, E. (2012). Estimating coverage of a women's group intervention among a population of pregnant women in rural Bangladesh. BioMed Central Pregnancy and Childbirth, 12, 1-7.

Zhelyazkova, N. (2013). Fathers' use of parental leave. What do we know? UNU-MERIT working paper series. United Nations University, 22, 1-41. 